Blaxter, K. L., Wood, W. A. \& MacDonald, A. M. (1953). Brit. F. Nutr. 7, 34.

Brown, F. (1953). Nature, Lond, I7r, 790.

Christensen, F. \& Dam, H. (I95I). Acta pharm. tox., Kbh., 7, 167.

Dam, H. \& Granados, H. (1951). Acta pharm, tox., Kbh., 7, 181.

Dam, H. \& Granados, H. (1952). Acta pharm. tox., Kbh., 8, 47.

Dam, H., Kruse, I., Prange, I. \& Sondergaard, E. (1948). Biochim. biophys. Acta, 2 , 501.

Dam, H., Kruse, I., Prange, I. \& Sondergaard, E. (195 I). Acta physiol. scand. 22, 299.

Dam, H., Prange, I. \& Søndergaard, E. (1951). Experientia, 7, I84.

Dam, H., Prange, I. \& Søndergaard, E. (I952a). Acta pharm. tox., Kbh., 8, I.

Dam, H., Prange, I. \& Søndergaard, E. (I952 b). Acta pharm. tox., Kbh., 8, 23.

Elzén, S. (1932a). Svensk VetTidskr. 37, 197.

Elzén, S. (1932b). Svensk VetTidskr. 37, 369.

Emmerie, A. \& Engel, C. (1938). Rec. Trav. chim. Pays-Bas, 57, 1351.

Hjärre, A. \& Lilleengen, K. (1936a). Virchows Arch. 297, 565 .

Hjärre, A. \& Lilleengen, K. (1936b). Nord. med. Tidskr. 48, 472.

King, E. J. (1946). Micro-Analysis in Medical Biochemistry. London: J. \& A. Churchill.

Knight, C. A., Dutcher, R. A., Guerrant, N. B. \& Bechdel, S. I. (1941). F. Dairy Sci. $24,567$.

Kon, S. K. \& Porter, J. W. G. (I95 r). Rep. nat. Inst. Dairy., Reading, 1951.

Moore, T., Sharman, I. M. \& Ward, R. J. (1953a). Biochem. F. (In the Press.)

Moore, T., Sharman, I. M. \& Ward, R. J. (1953b). Biochem. $\mathfrak{F} . \mathbf{5 3}$, xxxi.

Pavcek, P. L. \& Shull, G. M. (1942). F. biol. Chem. 146, 35 I.

Sullivan, M., Kolb, L. \& Nicholls, J. (r942). Johns Hopk. Hosp. Bull, 70, I77.

Weil-Malherbe, H. (1948). Annu. Rev. Biochem. 27, 1.

Wiese, A. C., Johnson, B. C. \& Nevens, W. B. (1946). Proc. Soc. exp. Biol., N. Y., 63, 521.

Zacharias, L., Goldhaber, P. \& Kinsey, V. E. (1950). F. Nutr. 42, 359.

\title{
Absence of Correlation between Fatty Changes in the Liver and Impairment of Water Diuresis in Protein-deficient Mice
}

\author{
By H. HELLER AND K. E. BLACKMORE \\ Department of Pharmacology, University of Bristol
}

(Received 22 April 1953)

It has been shown repeatedly that in rats the diuretic response to water administration can be decreased by dietary measures. Such decreases have been shown to occur in rats kept on low-protein $(0.5 \%$ ) diets containing 7.5-15.5\% fat (Dicker, Heller \& Hewer, I946; Heller \& Dicker, 1946-7; Dicker, 1950). Similar findings in the same species were made by Leslie \& Ralli (1947), who used a diet containing $8 \%$ protein and $38 \%$ fat. Shay, Kolm \& Fels (I945), whose rats received a diet containing $28 \%$ protein and $60 \%$ fat, reported likewise an impairment of water diuresis. Fatty changes in the liver can be produced either by protein-deficient or by high-fat diets; they may be presumed, or in some cases have actually been shown (Heller \& Hewer, unpublished results; György, 1944; Shay et al. 1945) to occur with the diets discussed. Are these fatty changes or rather the biochemical or circulatory (Himsworth, I947; Hartroft, 1949) events in the liver associated with them the common factor in the alterations of the water metabolism obtained with such widely different nutritional régimes? In view of this possibility and in view of current hypotheses which try to link changes of water metabolism with impairment of liver function, it 
seemed of interest to investigate whether a relationship between reduced water diuresis and incidence and intensity of hepatic fatty changes could be established.

Mice were chosen as experimental animals in preference to rats because alterations of their water metabolism could be expected to occur after shorter periods of feeding with the experimental diets.

\section{Experimental animals}

METHODS

Adult male albino mice, weighing from 22 to $30 \mathrm{~g}$, were used.

\section{Diets}

Diets and water were given unrestricted. The following diets were used (the figures denote percentages).

(I) Stock diet (SS). Wheat seed 22.7, barley meal 19.5 , linseed cake (foreign) 19.5, decorticated groundnut meal 19.5 , dried separated milk 2.4 , white fish meal 4.8 , meadow hay $9 \cdot 8$, cod-liver oil I 8 . This diet contains $25.6 \%$ protein (crude), $4.9 \%$ fat (ether extract) and $45.2 \%$ carbohydrate (Woodman, I952); it provides 327 Cal./100 g. All animals were kept on this diet for 4 weeks at least before an experimental diet was given.

(2) Control diet $(S F)$. Casein $18 \cdot 0$, wheat starch $63^{\circ} 0$, hardened groundnut oil $12 \cdot 0$, cod-liver oil $3^{\circ}$, Steenbock salt mixture (Hawk \& Bergeim, I942) $4^{\circ}$, supplemented by $50 \mathrm{mg}$ vitamin B-complex powder of Crookes Laboratories, Ltd. (which contains $0.4 \%$ thiamine, $0.5 \%$ riboflavin, $0.18 \%$ pyridoxin and $4.0 \%$ nicotinamide) and $6 \mathrm{mg}$ tocopheryl acetate per $100 \mathrm{~g}$ diet. Sufficient water $(3 \circ \mathrm{ml} / \mathrm{r} / 00 \mathrm{~g})$ was added to give the mixture the consistency of a thick paste. The diet then provided approximately $300 \mathrm{Cal} / \mathrm{r} 100 \mathrm{~g}$. It had the same fat content as the protein-deficient diet BB.

(3) Protein-deficient diets. (a) Low-casein, high-carbohydrate diet (BB): casein 0.5 , wheat starch $80^{\circ} 5$, hardened groundnut oil 12.0 , cod-liver oil $3^{\circ}$, salt mixture $4^{\circ} \mathrm{O}$, vitamin supplements and water as for diet SF. This diet supplied approximately $300 \mathrm{Cal} . / \mathrm{I} 00 \mathrm{~g}$.

(b) Low-casein, high-carbohydrate choline diet (BC): this diet had the same composition as diet $\mathrm{BB}$ but contained in addition $50 \mathrm{mg}$ choline chloride per $100 \mathrm{~g}$ (Best, Hartroft, Lucas \& Ridout, r949; Best, Lucas, Ridout \& Patterson, r950). The choline chloride was dissolved in water and the solution sprayed on a thin layer of food. The concentration of choline used may have been too low to exert a maximal lipotropic effect but the requirements of adult mice on a diet as low in protein as diet $\mathrm{BB}$ are not known.

(c) Vegetable, low-protein diet (TT): minced turnips $8 \mathrm{r}^{\circ} 5$, wheat starch $7 \cdot 0$, hardened groundnut oil 3.5 , cod-liver oil $4^{\circ} 0$, salt mixture $4^{\circ}{ }^{\circ}$; vitamin supplements as for diet BB. This diet had a protein equivalent of $0.4 \%$ and contained the equivalent of $75.6 \mathrm{mg}$ choline chloride per roo $\mathrm{g}$ (Engel, 1943 ); it provided approximately roo Cal./100 g (Woodman, 1952).

Diets $\mathrm{SF}, \mathrm{BB}$ and $\mathrm{BC}$ were equi-calorific; diet TT was not only much lower in calories but differed from the others in consistency and bulk. 


\section{Measurements of food intake}

Changes in food intake were estimated by placing mice singly in specially constructed metabolism cages. These were provided with food troughs which could not be upset by the animal and which had a cover with an opening only just large enough to admit the head of the mouse. Weighed amounts of food in excess of the daily requirements of healthy mice were provided. In spite of these precautions, some scattering of food could not be prevented. The metabolism cages were therefore placed on several layers of filter paper, the scattered food was separated from the faeces each morning and added to the food in the troughs which were then weighed to $0 . \mathrm{I} \mathrm{g}$. Since evaporation of water from the food was not controlled, the figures for food intake are only approximate.

\section{Determinations of protein concentration in plasma}

The copper-sulphate method of Phillips, Van Slyke, Dole, Emerson, Hamilton $\&$ Archibald (1945) was used in conjunction with the formula of Hoch \& Marrack (1945). The applicability of this formula to rat plasma has been shown by Dicker ( $1948 a$ ). Mouse plasma was found to have approximately the same water content as that of rats. The mean water content of the plasma of twelve adult mice on diet SS was $91 \cdot 8 \pm 0.23$ (S.E. of twelve observations) $\%$ as compared with $91 \cdot 4 \pm 0 \cdot 13 \%$ in rats (Dicker, $1948 b$ ).

\section{Estimation of total lipids of liver}

A gravimetric method was used. Six or more mouse livers were placed into a small beaker, weighed and dried at $10 I^{\circ}$ for $48 \mathrm{~h}$. The livers were then powdered in the same beaker, re-weighed and the powder transferred into a tared Soxhlet thimble and again weighed. A Bloor mixture ( 3 parts absolute ethanol and I part diethyl ether) was used for extraction in a small Soxhlet apparatus with which a tared round-bottomed flask of $100 \mathrm{ml}$. capacity had been connected. The solvent was allowed to reflux for $24 \mathrm{~h}$ after which the ethanol and ether were removed by blowing air through the mixture; the flask was then placed into a desiccator for $24 \mathrm{~h}$ and weighed.

\section{Histological methods}

Frozen and paraffin sections of liver were cut and stained with Weigert's iron haematoxylin and Scharlach $R$, and haematoxylin and eosin respectively.

\section{Response to water administration (water diuresis)}

Mice whose responses to water administration were to be compared were randomly divided into groups before being put on different diets and were kept under identical environmental conditions before and during the experiments. They had free access to water up to the beginning of the experiment. Two doses of $5 \mathrm{ml}$. water/roo $\mathrm{g}$ bodyweight were then given by stomach tube with an interval of $\mathrm{I} h$. Details of the procedure used have been described previously (Heller \& Blackmore, 1952). 
RESULTS

\section{Effects of protein-deficient diets on food intake and body-weight}

Table I shows that marked anorexia developed when mice were fed on the proteindeficient diets. Body-weight decreased steadily. The faeces were of a softer consistency than usual but diarrhoea was observed in rare instances only.

Table I. Percentage changes in food intake and body-weight in adult mice fed on proteindeficient diets. Four animals were used for each diet. Mean food intake and mean body-weight at the end of the Ist day are taken as 100. Absolute mean values of food intake and body-weight for the Ist day are in parentheses. Water was given ad lib.

\begin{tabular}{|c|c|c|c|c|c|c|c|c|c|c|}
\hline \multirow[b]{2}{*}{$\begin{array}{c}\text { Days on } \\
\text { diet }\end{array}$} & \multicolumn{2}{|c|}{$\begin{array}{c}\text { Diet SS } \\
\text { Mean percentage } \\
\text { change }\end{array}$} & \multicolumn{2}{|c|}{$\begin{array}{c}\text { Diet } S F \\
\text { Mean percentage } \\
\text { change }\end{array}$} & \multicolumn{2}{|c|}{$\begin{array}{c}\text { Diet BB } \\
\text { Mean percentage } \\
\text { change }\end{array}$} & \multicolumn{2}{|c|}{$\begin{array}{c}\text { Diet } \mathrm{BC} \\
\text { Mean percentage } \\
\text { change }\end{array}$} & \multicolumn{2}{|c|}{$\begin{array}{c}\text { Diet TT } \\
\text { Mean percentage } \\
\text { change }\end{array}$} \\
\hline & $\begin{array}{l}\text { Food } \\
\text { intake }\end{array}$ & $\begin{array}{l}\text { Body- } \\
\text { weight }\end{array}$ & $\begin{array}{l}\text { Food } \\
\text { intake }\end{array}$ & $\begin{array}{l}\text { Body- } \\
\text { weight }\end{array}$ & $\begin{array}{l}\text { Food } \\
\text { intake }\end{array}$ & $\begin{array}{l}\text { Body- } \\
\text { weight }\end{array}$ & $\begin{array}{l}\text { Food } \\
\text { intake }\end{array}$ & $\begin{array}{l}\text { Body- } \\
\text { weight }\end{array}$ & $\begin{array}{c}\text { Food } \\
\text { intake }\end{array}$ & $\begin{array}{l}\text { Body- } \\
\text { weight }\end{array}$ \\
\hline I & $\begin{array}{c}100 \\
(7.5 \mathrm{~g})\end{array}$ & $\begin{array}{c}100 \\
(24.7 \mathrm{~g})\end{array}$ & $\begin{array}{c}100 \\
(9 \cdot 25 \mathrm{~g})\end{array}$ & $\begin{array}{c}100 \\
\left(25^{\circ} 8 \mathrm{~g}\right)\end{array}$ & $\begin{array}{l}100 \\
(6 \cdot 0 \mathrm{~g})\end{array}$ & $\begin{array}{l}100 \\
(22 \cdot 3 \mathrm{~g})\end{array}$ & $\begin{array}{c}100 \\
(6 \cdot 25 \mathrm{~g})\end{array}$ & $\begin{array}{c}100 \\
(38.6 \mathrm{~g})\end{array}$ & $\begin{array}{c}100 \\
(9.5 \mathrm{~g})\end{array}$ & $\begin{array}{c}100 \\
(29 \cdot 8 \mathrm{~g})\end{array}$ \\
\hline 2 & 140 & I I I & 92 & 107 & 100 & 93 & 80 & 100 & $89 \cdot 5$ & 89.0 \\
\hline 3 & I 36 & 112 & 125 & 107 & 100 & $9 I$ & 48 & 98 & $84^{\circ} 0$ & 84.0 \\
\hline 4 & I23 & III & 97 & 112 & 100 & 91 & 44 & 95 & 79.0 & $80 \cdot 0$ \\
\hline 5 & 63 & 114 & 108 & I ro & 92 & 90 & $5^{2}$ & 92 & $71 \cdot 0$ & $76 \cdot 5$ \\
\hline 6 & 89 & 114 & 105 & 109 & 58 & 87 & 44 & 91 & $79 \cdot 0$ & 74.0 \\
\hline 7 & 98 & I I I & 103 & 109 & 63 & 87 & 44 & 90 & 73.5 & 69.0 \\
\hline 8 & 88 & 112 & II 4 & 108 & 66 & 88 & 52 & 89 & $39 \cdot 6$ & 65.5 \\
\hline 9 & 85 & I I I & 108 & Iro & 50 & 84 & 54 & 87 & - & - \\
\hline 10 & - & 109 & - & I I 2 & - & - & 44 & 87 & - & - \\
\hline
\end{tabular}

\section{Level of plasma proteins}

The mean protein level in fifteen controls fed on diet SS was $6 \cdot 39 \pm 0.18 \mathrm{~g} / \mathrm{r} 00 \mathrm{ml}$. In animals fed on diet BB the mean plasma-protein level had declined by $26.2 \%$ (fourteen animals) after $8-9$ days, by $27.8 \%$ (twelve animals) after $14-15$ days, and by $29.3 \%$ (eighteen animals) after 20-21 days. Mice fed on diet BC showed a much smaller decrease, namely $7.8 \%$ (ten animals) after 8-9 days and $9.0 \%$ (six animals) after I4-I 5 days. This recalls a similar observation by Alexander $\&$ Engel (I952) in rats. The plasma-protein level in mice fed on diet TT fell by $18.5 \%$ (twelve animals) in 14 days. Single animals kept on the protein-deficient diets did not provide sufficient blood for plasma-protein estimation; the plasma of several mice had to be pooled. Means but no standard errors are therefore given.

Fatty changes in the liver

Histological findings. Table 2 shows that no fatty changes were seen in animals fed on the stock diet SS though slight amounts of fat were visible in the livers of mice that had been kept on the control diet SF for 7 days. This diet contained the same proportion of fat as diets $\mathrm{BB}$ and $\mathrm{BC}$. The fatty changes which occurred in the animals kept on the deficient diets were rapid and marked. Judging from the histological evidence (Table 2) the greatest quantities of fat accumulated in the livers of the 
mice on the choline- and protein-deficient diet BB. Addition of choline to this diet gave, as one would expect (Fouts, 1943; Best, 1950; Elvehjem, 1952) only partial protection but it should be stressed again that the amounts of choline added were probably suboptimal. Comparatively little fat was found with the low-calorie vegetable diet TT, the choline content of which was high (see p. 350).

Table 2. Histological assessment of the intensity of fatty changes in the livers of mice fed on the experimental diets. The quantity of lipid present as gauged from slides stained with Scharlach $R$, is recorded as $0,+,++,+++$, or ++++

$\begin{array}{ccc}\text { Days on diet } & \begin{array}{c}\text { Control } \\ \text { diet SS }\end{array} & \text { Diet BB } \\ I & 0 & + \\ 2-3 & 0 & +++ \\ 4-5 & 0 & ++++ \\ 6-7 & 0 & ++++ \\ 8 & 0 & +++ \\ 10 & 0 & ++\end{array}$
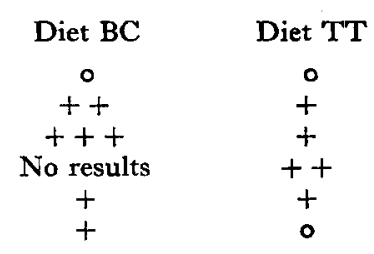

The accumulation of fat in the livers of animals fed on diets BC and TT was only a passing phase: little fat was demonstrable in the livers of mice kept on diet $\mathrm{BC}$ for Io days and none in the livers of mice kept on diet TT for the same period. These findings agree with observations on the absence of fatty changes in rats kept on diet TT for about $3^{6}$ days (Dicker et al. 1946).

Table 3. Chemical estimation of total lipid and water content of livers of mice fed on the experimental diets

$\begin{array}{ccccc}\text { Diet } & \text { No. of animals } & \text { Days on diet } & \begin{array}{c}\text { Mean water } \\ \text { content } \\ \text { (g/roo } g \\ \text { liver) }\end{array} & \begin{array}{c}\text { Mean total } \\ \text { lipid content } \\ \text { (g/loo } g \\ \text { wet liver) }\end{array} \\ \text { SS } & 22 & 8 & 69 \cdot 3 & 6 \cdot 2 \\ \text { SF } & 6 & 9 & 68.8 & 7 \cdot 6 \\ \text { BB } & 17 & 8 & 64 \cdot 7 & 15 \cdot 3 \\ \text { BC } & 16 & 9 & 69 \cdot 3 & 8 \cdot 7 \\ \text { TT } & 10 & 9 & 70 \cdot 4 & 5 \cdot 5\end{array}$

Chemical determinations. The results in Table 3 agree with the histological results: the livers of animals on diet $\mathrm{BB}$ were found to contain considerably more fat than those of controls on either diet SS or diet SF: the mean fat content of the livers of mice kept on diet BC for 9 days was perhaps higher than normal, but there was no increase in the livers of animals fed on diet TT for 9 days.

\section{Response to water administration}

Fig. I A shows the diuretic response to water in mice on the control diets SS and SF. The difference shown, although significant, was slight. A decrease in rate and volume of the renal excretion of water of an entirely different order was, however, observed in the animals on the protein-deficient diet BB (Fig. I $B$ ). The decrease was pronounced after 7 days on that diet, i.e. when hepatic fatty changes were maximal 
(see Table 2) and became more marked after Io days when fatty changes were present but were much less pronounced (Table 2). Water diuresis was also impaired, though to a lesser degree, in animals fed on the choline-enriched diet BC. For example in a series of sixteen mice kept on diet $\mathrm{BC}$ for 7 days the mean volume of urine 90 min after the second administration of water was $45 \cdot 3 \pm 6 \cdot 8 \%$ of that of the controls; it

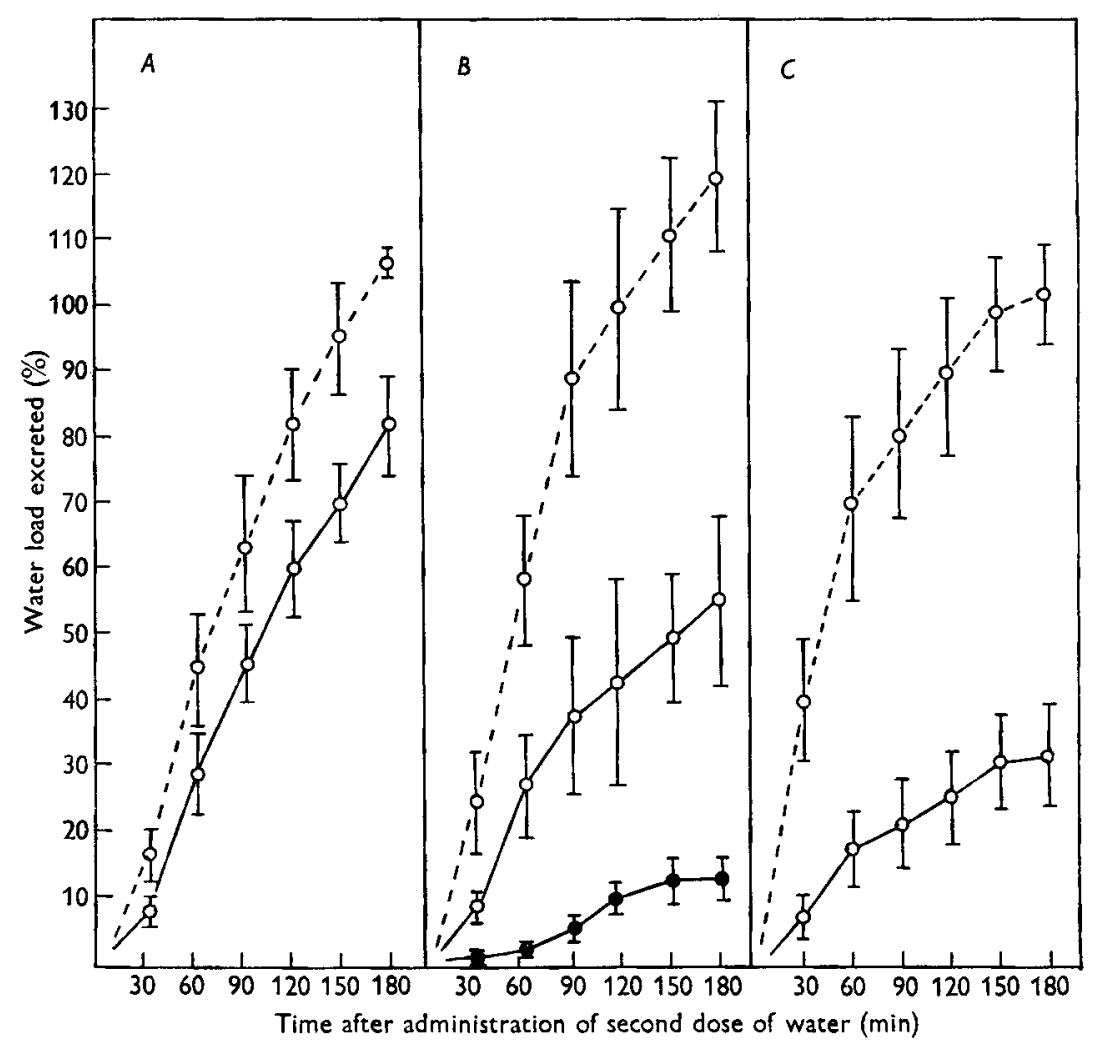

Fig. I. Water diuresis in mice fed on control and on protein-deficient diets (means and standard errors). (A) $\mathrm{O}_{-}-\mathrm{O}$, mice fed on the stock diet SS (twenty-four animals); $\mathrm{O}-\mathrm{O}$, mice fed on the

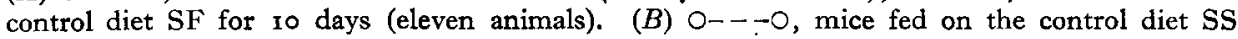
(fourteen animals); $O-O$, mice fed on the protein-deficient diet BB for 7 days (fourteen animals); - -1 mice fed on the protein-deficient diet $\mathrm{BB}$ for ro days (fourteen animals); (C) $\mathrm{O}_{-}-\mathrm{O}$, mice fed on the control diet SS (twelve animals); $\mathrm{O}-\mathrm{-O}$, mice fed on the proteindeficient vegetable diet TT for Io days (twelve animals). For further details see text.

was $3 \mathrm{I} \cdot 8 \pm \mathrm{I} I \cdot 5 \%$ of the control value, in mice kept on diet BC for Io days. Fig. $\mathrm{I} C$ shows a significant depression of the diuretic response in mice fed for to days on the low-protein vegetable diet TT. No increase of liver fat could be demonstrated in these animals (Table 2) or in another series of mice fed on the same diet for 9 days (Table 3).

\section{DISCUSSION}

Total blood volume was not measured in our animals; it is therefore impossible to say whether the changes in plasma-protein concentration observed represented mainly changes in the body's protein stores or were due to an increase of the circulating plasma volume, or both. However, it seems justifiable to describe the mice on 
protein-poor diets as 'protein-deficient animals' provided it is recognized that any abnormal findings in such animals are not necessarily related to the lack of protein only, but may also have been caused by undernutrition due to anorexia or to diminished absorption or utilization of other constituents of the diets.

It has been shown in rats (Best \& Huntsman, 1934-5; Mulford \& Griffith, 1942) that starvation or a fall in food intake will cause a reduction in liver fat, when fatty changes have been established by dietary means. In fasting mice total liver lipids increase during the first 2 days but a decrease to less than normal values follows on the $3^{\text {rd- }} 5^{\text {th }}$ day of withdrawal of food (Hodge, MacLachlan, Bloor, Welch, Kornberg \& Falkenheim, 1948). Since our animals after a few days on a diet deficient in protein developed a marked anorexia it was not surprising to find that the fatty changes in the liver decreased in intensity as feeding with the various protein-deficient diets was continued.

Water given to mice on protein-deficient diets was excreted at a markedly lower rate than by the controls. This impairment of water diuresis is unlikely to have been due to an insufficient water load since it occurred in animals which had not been deprived of water before the experiment and when the mean load of administered water was about $8 \%$ of the animals' body-weight. These results resemble previous findings in rats on similar protein-deficient diets (Dicker et al. 1946; Heller \& Dicker, 1946-7; Dicker, 1950) with the difference that the decreased response to water developed more rapidly in mice, i.e. within a few days rather than weeks on the deficient diets.

The failure or partial failure of the mice on protein-deficient diets to respond to water administration was not related to the degree of fatty changes found in their livers: animals kept on a protein-deficient, high-carbohydrate diet with the same fat and calorie content as that of their controls showed, from the 7 th to the Ioth day, a decrease of liver fat but a pronounced increase in their inability to excrete administered water. Again, mice kept on a diet deficient in vegetable protein of low calorific value showed a marked depression of water diuresis without, at that stage, any increase in liver fat.

There are some parallels between our results and observations in clinical states of protein deficiency. Appetite in kwashiorkor has been reported as poor (Dean, 1952) and 'in the later stages of all severe cases is lost entirely' (Trowell, Davies \& Dean, 1952). A decreased response to water administration in infants suffering from kwashiorkor has been observed in a number of instances (Heller \& Schnieden, unpublished results). Since the chain of events leading to impairment of water diuresis is not well understood in either experimental protein deficiency or in kwashiorkor, it would be hazardous to ascribe the decreased response to water administration in the two conditions to the same mechanism.

\section{SUMMARY}

I. Adult mice fed on a protein- and choline-deficient diet, isocaloric with a fully adequate control diet developed marked anorexia. Addition of choline to the deficient diet did not prevent anorexia. 
2. Fatty changes in the liver developed rapidly in mice on the protein-deficient isocaloric diet, but decreased in intensity as feeding with the deficient diet was continued.

3. When a vegetable diet poor in calories and protein but probably adequate in choline was given, anorexia was again demonstrable. Fatty changes in the liver remained inconspicuous and no excess fat was found after Io days on this diet.

4. Water diuresis was impaired in the animals fed on the protein-deficient diets. There was no correlation between the presence or intensity of fatty changes in the liver and the response to water administration.

We wish to thank Messrs Crookes Laboratories and in particular Dr A. R. H. Hicks for supplying us with vitamin B-complex powder.

\section{REFERENCES}

Alexander, H. D. \& Engel, R. W. (r952). F. Nutr. 47, 36r.

Best, C. H. (1950). Fed. Proc. 9, 506.

Best, C. H., Hartroft, W. S., Lucas, C. C. \& Ridout, J. H. (1949). Brit. med. F. ii, I001.

Best, C. H. \& Huntsman, M. E. (1934-5). F. Physiol. 83, 255.

Best, C. H., Lucas, C. C., Ridout, J. H. \& Patterson, J. M. (1950). F. biol. Chem. 186, 3 r 7.

Dean, R. F. A. (1952). East Afr. med. Y. 29, I.

Dicker, S. E. (1948a). $\mathcal{F}$. Physiol. ro7, i $P$.

Dicker, S. E. (1948b). Biochem. F. 43, 453.

Dicker, S. E. (1950). Biochem. $\mathcal{F} .46,53$.

Dicker, S. E., Heller, H. \& Hewer, T. F. (1946). Brit. F. exp. Path. 27, 158.

Elvehjem, C. A. (1952). Science, I16, 521 .

Engel, R. W. (1943). F. Nutr. 25, 44I.

Fouts, P. J. (1943). F. Nutr. 25, 2 I 7.

György, P. (1944). Amer. F. clin. Path. 14, 67.

Hartroft, W. S. (1949). Trans. 8th Conference on Liver Injury. New York: Josiah Macy Foundation.

Hawk, P. B. \& Bergeim, O. (1942). Practical Physiological Chemistry, i th ed. London: Churchill.

Heller, H. \& Dicker, S. E. (1946-7). Proc. R. Soc. Med. 40, 351 .

Heller, H. \& Blackmore, K. E. (1952). F. Endocrin. 8, 224.

Himsworth, H. P. (1947). Lectures on the Liver and its Diseases. Oxford: Blackwell.

Hoch, H. \& Marrack, J. (1945). Brit. med. F. ii, I5I.

Hodge, H. C., MacLachlan, P. L., Bloor, W. R., Welch, E., Kornberg, S. L. \& Falkenheim, M. (I948). Proc. Soc. exp. Biol., N.Y., 67, 137.

Leslie, S. H. \& Ralli, E. P. (1947). Endocrinology, 4r, I.

Mulford, D. J. \& Griffith, W. H. (1942). F. Nutrit. 23, 91.

Phillips, R. A., Van Slyke, D. D., Dole, V. P., Emerson, K. Jr., Hamilton, P. B. \& Archibald, R. M. (1945). Copper Sulfate Method for Measuring Specific Gravities of Whole Blood and Plasma. New York: Josiah Macy Jr. Foundation.

Shay, H., Kolm, R. \& Fels, S. S. (I945). Gastroenterology, 4, 257.

Trowell, H. C., Davies, J. N. P. \& Dean, R. F. A. (1952). Brit. med. F. ii, 798.

Woodman, H. E. (1952). Bull. Minist. Agric., Lond., no. 48. 